\title{
Os sertões: uma leitura lacunar
}

Raimundo Carvalho
Universidade Federal do Espírito Santo

Resumo: A despeito da reconhecida importância de Os sertōes, de Euclides da Cunha, para a constituição do pensamento social brasileiro, procuramos ressaltar, nesta leitura, os aspectos estéticos e literários da obra, proclamando a sua autonomia de obra artística, sem, contudo, negar as suas relaçôes com a ciência e com a realidade histórica e social descrita no livro.

Palavras-chave: Sertão, Ciência, Literatura.

"Em minha cabeça degolada amadurece um pensamento impossível."

Interessa-nos, nesta proposta de leitura, apreender Os sertões em sua complexidade de obra literária, submetida à análise que desvende seus modos de construção e significação. Mas não se trata de ignorar sua relevância para o pensamento histórico, social e político brasileiro, pois seu grau de referencialidade não oblitera, nem desautoriza leitura que a libere para uma aventura de linguagem. Por isso, gostaríamos de propor uma reflexão sobre aspectos literários e formais de Os sertôes, de Euclides da Cunha, obra que realiza, no dizer do próprio autor, um consórcio entre ciência e arte. Na carta em que

1 CACASO. Lero-lero, p. 12. 
se dirige ao crítico José Veríssimo, Euclides da Cunha defende o emprego de termos técnicos extraídos das várias disciplinas científicas. Escreve ele:

Eu estou convencido que a verdadeira impressão artística exige, fundamentalmente, a noção científica do caso que a desperta - e que, nesse caso, a comedida intervenção de uma tecnografia própria se impõe obrigatoriamente - e é justo desde que se não exagere ao ponto de dar um aspecto de compêndio ao livro que se escreve, mesmo porque em tal caso a feição sintética desapareceria e com ela a obra de arte. ${ }^{2}$

Estas linhas deixam bem claras a pretensão e a consciência de Euclides da Cunha de, ao escrever Os sertôes, estar compondo uma obra de caráter literário e, portanto, passível de um julgamento estético. A arte aí entra com o seu poder de síntese, domando o empenho analítico, para que este não sobrecarregue o escrito com a mera referencialidade dos dados frios da ciência. Neste consórcio entre ciência e arte, o papel determinante cabe ao segundo. Cabe ao artista, auxiliado por uma variedade de saberes incorporados à sua prática perceptiva, amalgamar o material num todo indivisível, criando, assim, a aparência de um objeto perfeito e de existência autônoma.

A precedência da arte face à ciência não diminui a importância de Os sertões como obra de pensamento, aliás, obra fundadora da tradição do pensamento crítico brasileiro, uma vez que, para o seu autor, o sentido estético da obra, longe de se limitar aos aspectos ornamentais da superfície textual, nasce da exigência de uma reflexão rigorosa sobre a condição humana.

Como homem de seu tempo, Euclides da Cunha professou ideias que hoje já não têm respaldo científico, mas seria um engano avaliar o valor de sua obra pelos acertos ou pelos erros de suas opções teóricas e concepções filosóficas. A grandeza do gesto euclidiano deve ser percebida no seu empenho em pensar, ainda que com algumas categorias hoje postas em descrédito, a nossa realidade social e política, legando-nos, como povo e nação, um retrato em cores vivas e traços expressivos.

Esse efeito estético duradouro, exaustivamente perseguido por Euclides, não conflita, de modo algum, com a justa pretensão de ser Os sertões livro de historiador, ainda que uma espécie particular de historiador, o "narrador sincero" de Taine, diferente dos "autores que não alteram nem uma data, nem

\footnotetext{
2 GALVÃO; GALOTTI. Correspondência de Euclides da Cunha, p. 144.
} 
uma genealogia, mas desnaturam os sentimentos e os costumes, que conservam o desenho dos acontecimentos mudando-lhes a cor, que copiam os fatos desfigurando a alma (...).,"

Apontar o caráter primordialmente literário de Os sertões não implica situá-lo no campo da ficção, mas, sim, reconhecê-lo como um texto cujo sentido só pode ser intuído se atentarmos para sua intrincada configuração verbal. Só mesmo percorrendo com atenção a trama textual de Os sertões podemos perceber, nos interstícios dos variados discursos das certezas científicas, as incertezas e ambiguidades do signo literário.

Sob o ponto de vista macroestrutural, Os sertões apresentam aspecto triádico. Três são suas partes: "A terra”, "O homem" e "A luta”. Três são também seus modos de agenciamento do signo: descrição, interpretação e narração. Estes temas e modos se interpenetram, compondo um tecido intrincado e coeso, cujo efeito de unidade resulta em autonomia frente ao real que a obra quis refletir e no qual ela se inspirou.

Por obedecer a leis internas ao funcionamento do signo literário, palavras, pensamentos, personagens, cenários e ações que compõem Os sertões sobrevivem para além da realidade da qual foram extraídos, mas a literariedade do livro não subtrai seus vínculos com ela. Ao contrário, a realidade sai enriquecida em sua fricção com o discurso literário, porque é próprio deste captar a diversidade, que é o modo de ser do real. A linguagem que tece esse texto, feito de fragmentos de outros textos, não tem como suporte voz única, mas um concerto bem urdido de vozes afinadas pelo gesto escritural que incorpora textos e ideias alheias, subordinando-os à sua maneira de agenciar o signo literário.

A autonomia de Os sertões frente ao seu referente deriva do seu modo de intencionar, uma vez que a potência criadora se deixa enfeitiçar pelo aspecto mágico da linguagem que, ao expor o drama da formação do Brasil, expõe também o seu drama constitutivo e se interroga, num processo de autorreflexividade. O leitor de Os sertões que desviar, um instante, sua atenção do conteúdo da prosa euclidiana se surpreenderá com expressiva modulação de frases, plasticamente construídas.

Mário de Andrade, viajando pelo Nordeste, relata, em O turista aprendiz, o impacto sofrido ao contato direto com a paisagem e a realidade do sertão. Sua primeira reação é contra o livro de Euclides, a quem acusa de

3 CUNHA. Os sertões, p. 67. 
falsificação e de fazer "literatura": "Euclides transformou em brilho de frase sonora e imagens chiques, o que é cegueira insuportável deste solão, transformou em heroísmo o que é miséria pura, em epopéia..." Mas o alvo da crítica de Mário é, sobretudo, certos leitores de Euclides, "os nordestinos arranjados, cheios de regionalismo e literatice", que preferem mascarar a realidade a transformá-la.

Ao final da viagem, depois de fazer algumas descrições que lembram as do próprio Euclides ("larguezas formidáveis e no longe à direita a serra de Borborema menos recortada, ondulando estendida.”'), Mário confessa sua impotência:

Mil cento e cinco quilômetros devorados. É uma indigestão formidável de amarguras, de sensações desencontradas, de perplexidades, de ódios. Um ódio surdo... Quase uma vontade de chorar... Uma admiração que me irrita. Um coração penando de amor doloroso. Não estou fazendo literatura não. Eu tenho a coragem de confessar que gosto de literatura. Tenho feito e continuarei fazendo muita literatura. Aqui não. Repugna minha sinceridade de homem fazer literatura diante desta monstruosidade de grandezas que é a seca sertaneja do Nordeste. Que miséria e quanta gente sofrendo... É melhor parar. Meu coração está penando por demais... ${ }^{7}$

Mário de Andrade, em que pese o exagero do seu julgamento, aponta, acertadamente, para o caráter "literário" do livro de Euclides. Embalado pelas potencialidades mágicas da linguagem, o engenheiro de Os sertôes se doa integralmente ao processo escritural de recriar, em chave dramática, a nossa identidade profunda, pondo nisso toda a força de seu imaginário, aliada ao pendor para a observação direta e para o estudo das fontes, legando aos leitores retrato, nada falso e nada lisonjeiro, de nossa face obscura.

Esboçaremos adiante uma leitura pelo avesso ou pelas bordas de Os sertões. Sem desconhecer os seus laços com a realidade, o que nos interessa é examinar-lhe a materialidade sígnica, procurando perceber sua sobrevivência como obra literária. Ao incorporar dimensão visionária a ponto de vista objetivo da realidade, Euclides atraiu para sua obra a desconfiança dos homens de ciência e ação, e, ao submeter seu imaginário aos paradigmas da ciência de sua época,

4 ANDRADE. O turista aprendiz, p. 265.

5 ANDRADE. O turista aprendiz, p. 265.

6 ANDRADE. O turista aprendiz, p. 300.

7 ANDRADE. O turista aprendiz, p. 301. 
produziu uma obra de caráter híbrido, propondo ao leitor uma aventura de linguagem que potencialmente se atualiza toda vez que for percebida na sua dimensão plural de obra aberta.

A começar do título, a obra euclidiana já se põe nos termos da pluralidade. Numa sequência de obras como O sertanejo, de José de Alencar, Sertão, de Coelho Neto, e Pelo sertão, de Afonso Arinos, Os sertões se destaca ao assumir o plural a que as outras não almejam. Embora partilhando com elas, além do referente geográfico, certo padrão de uso do idioma, principalmente com as duas últimas, afasta-se delas, no entanto, por adicionar à matéria uma visão histórica que se choca com a visão pitoresca que permeia a ficção regionalista.

Numa crônica premonitória, ainda antes do fim da guerra de Canudos, em que comenta o livro de Coelho Neto, Machado de Assis afirma: "Se achardes no Sertão muito sertão, lembrai-vos que ele é infinito (...)” ${ }^{8}$. Adiante, o Bruxo do Cosme Velho prevê a publicação de livro sobre o episódio de Canudos quando este estiver concluído, atribuindo tal tarefa a outro Coelho Neto, de igual talento; profecia cumprida por Euclides cinco anos depois.

Numa perspectiva temporal ampliada, coube a Guimarães Rosa retomar, em chave crítica, essa tradição textual, produzindo síntese que supera visão histórica ideologicamente comprometida com preconceitos de época e visão pitoresca romanticamente idealizada. ${ }^{9}$ A síntese rosiana não anula, mas ilumina retroativamente o caminho até então percorrido. Uma das possibilidades de leitura do título da obra maior de Rosa é a de que o sintagma "grande sertão" seja referência à obra de Euclides, no que ela tem de grandioso, aéreo e plural; contraponteado pelas "veredas", o pequeno, o ínfimo, o terrestre e singular modo de ser dos seres e das coisas do sertão.

É interessante também perceber a ideia de conflito como valor semiótico que norteia a construção de Os sertões e não apenas como o seu assunto principal. O conflito se impõe, já nos dois primeiros parágrafos que constituem o incipit do livro, na descrição da natureza, cujos elementos são revolvidos e examinados desde as profundezas da terra:

O planalto central do Brasil desce, nos litorais do Sul, em escarpas inteiriças, altas e abruptas. Assoberba os mares; e desata-se em chapadões nivelados pelos visos das cordilheiras marítimas, distendidas do Rio Grande

8 ASsIS. Obra completa, v. 3, p. 765.

9 BOLLE. grandesertão.br ou: a invenção do Brasil, p. 165-235. 
a Minas. Mas ao derivar para as terras setentrionais diminui gradualmente de altitude, ao mesmo tempo que descamba para a costa oriental em andares, ou repetidos socalcos, que o despem da primitiva grandeza afastando-o para o interior.

De sorte que quem o contorna, seguindo para o norte, observa notáveis mudanças de relevos: a princípio o traço contínuo e dominante das montanhas, precintando-o, com destaque saliente, sobre a linha projetante das praias; depois, no segmento de orla marítima entre o Rio de Janeiro e o Espírito Santo, um aparelho litoral revolto, feito da envergadura desarticulada das serras, riçado de cumeadas e corroído de angras, e escancelando-se em baías, e repartindo-se em ilhas, e desagregando-se em recifes desnudos, à maneira de escombros do conflito secular que ali se trava entre os mares e a terra; em seguida, transposto o $15^{\circ}$ paralelo, a atenuação de todos os acidentes - serranias que se arredondam e suavizam as linhas dos taludes, fracionadas em morros de encostas indistintas no horizonte que se amplia; até que em plena faixa costeira da Bahia, o olhar, livre dos anteparos de serras que até lá o repulsam e abreviam, se dilata em cheio para o ocidente, mergulhando no âmago da terra amplíssima lentamente emergindo num ondear longínquo de chapadas... ${ }^{10}$

Trata-se de descrição travestida de narrativa. As formas verbais "desce", “desata-se", “diminui”, "descamba”, “despem”, etc, empregadas no primeiro parágrafo, produzem uma antropomorfização das forças da natureza em choque. No segundo parágrafo, acompanhamos a intromissão da presença humana no meio desta natureza revolta e um novo conflito se estabelece entre o olhar que perscruta e a natureza que não se deixa apreender facilmente, porque ela mesma se constitui em obstáculos que "repulsam" e "abreviam" o olhar daqueles que vivem "parasitariamente à beira do Atlântico", como "mercenários inconscientes" armados pela indústria bélica e pelos princípios civilizatórios europeus.

Portanto, "o conflito secular que ali se trava entre os mares e a terra" antecipa a dicotomia básica e constitutiva do nosso ser social, a "visão do litoral", do homem urbano, da Rua do Ouvidor, imitador compulsivo das modas estrangeiras e a "visão do sertanejo", "rocha viva da nacionalidade", na metáfora geológica de Euclides. Ecoa, também, nos parágrafos citados, o esquema básico

10 CUNHA. Os sertôes, p. 72-73. (Grifos nossos.)

11 CUNHA. Os sertões, p. 66. 
da profecia do Conselheiro de que "o sertão vai virar mar e o mar vai virar sertão". Chamamos atenção aqui para o aspecto conciliador da imagem proposta pelo Conselheiro: o sertão, inóspito e árido, vai se transformar, em virtude da ação redentora do trabalho coletivo, num lugar aprazível e fértil, como a zona costeira, o mar. A segunda parte da profecia deve ser entendida, não como uma inversão compensatória, fruto do ressentimento, mas como utopia generosa propondo uma possível unidade, em que o litoral se deixe sertanizar, ou seja, que encontre aqui mesmo os parâmetros civilizatórios que vai buscar alhures.

É a estrutura polifônica da prosa euclidiana, descrevendo ao mesmo tempo um olhar de sobrevoo, horizontalizante (dirigido à paisagem), e um olhar em profundidade, vertical, revelando as camadas do tempo e da história, que faz de Os sertões uma obra de literatura. Nesse sentido, o trecho inicial da obra funciona como uma célula-mãe, a partir da qual se disseminam os vários discursos, vozes e visões de mundo dos atores envolvidos no drama representado.

Propomos, portanto, uma leitura lacunar de Os sertões, apoiada nos vazios do texto, representados iconicamente pelas reticências. A abundância de reticências é marcante na composição da obra. Estão disseminadas em todo o livro, o que nos levou a elegê-las como principal recurso formal de sua organização textual. São cerca de 430 reticências, que, postas geralmente nos finais de parágrafos, cumprem variadas funções no discurso euclidiano.

Comentando a pontuação de Os sertões, Herbert Parente Fortes afirma:

Há no período euclidiano uma cadência fortemente acentuada, rica de pontuação, especialmente de vírgulas, travessões e reticências. Usa dos dois últimos com abundância, de mistura com polissíndetos, assíndetos, interjeições. Sua reticência exprime variadíssimos sentimentos fortes: quando a palavra perde o governo da expressão; em elevações místicas; para fazer sarcasmo, para silenciar o que é melhor não dizer expressamente; etc., etc. Muitas vezes, as suas reticências como que detém, de chofre, - derramando, - todo o acelerado de vírgulas do período. São aos milhares as reticências de Euclides, n'Os sertões. E há sempre em cada uma delas algo de novo, que resiste a toda disciplina. - Há muito dele mesmo neste sinal fonético-semântico. ${ }^{12}$

12 FORTES. Euclides: o estilizador de nossa história, p. 123. 
Modesto de Abreu diz, com outras palavras, algo semelhante:

A pontuação em Euclides da Cunha é em geral abundante, variada e lógica.

Entre os sinais que mais e melhor emprega estão as vírgulas, o ponto-e-vírgula, o travessão e as reticências.

Quanto a estas últimas, usa-as com adequado efeito psicológico, para sugerir, em fins de períodos, intenção irônica, e também para dar idéia de uma ação que se prolonga...

Em carta a Alberto Rangel, Euclides, a pretexto de solicitar revisão de texto seu, refere-se à sua "pontuação luxuriosa", para a qual pede respeito, indicando, assim, a importância desta no sistema expressional de sua obra. A pontuação euclidiana, além de sua necessidade lógica e expressiva, participa, junto com a ortografia, de um efeito visual que o autor manipula para confeccionar o seu texto. Comentando, em correspondência a Domício da Gama, a reforma ortográfica, Euclides dá a medida de sua íntima e sensorial relação com a escrita. Diz ele:

Há ali coisas inviáveis: a exclusão sistemática do y, tão expressivo na sua forma de âncora a ligar-nos com a civilização antiga e a eliminação completa do k, do hierático k (kapa como dizemos cabalisticamente na Álgebra)...

Como poderei eu, rude engenheiro, entender o quilômetro sem o k, o empertigado k, com as suas duas pernas de infatigável caminhante, a dominar distâncias? Quilômetros, recorda-me kilometro singularmente esmagado ou reduzido; alguma coisa como o relíssimo decímetro, ou grosseira polegada. ${ }^{15}$

É possível que não tenha escapado a Guimarães Rosa o uso icônico da ortografia e da pontuação em Os sertões, e dele deu testemunho em Sagarana, no qual disseminou reticências, chegando a usá-las, duas vezes, em "O burrinho

13 ABREU. Estilo e personalidade de Euclides da Cunha: estilística d'Os sertões, p. 176.

14 GALVÃO; GALLOTI. Correspondência de Euclides da Cunha, p. 338.

15 GALVÃO; GALLOTI. Correspondência de Euclides da Cunha, p. 335 
pedrês", seguidas de ponto de exclamação e novas reticências (...!...) para figurar o processo descrito: "Depois, o Calundu sungou a cabeça, e o sangue subiu atrás, num repuxo desta altura:...!..." ver a intenção de figurar o elemento gestual da conversação entre vaqueiros: "(...) e com cada carne esponjosa de frieira entre as unhas, que era isto:...!...." Em face desse conto, em que "a estória de um burrinho" vale a "história de um homem" ", como não se lembrar deste trecho de Os sertôes:

De feito, aquela campanha cruenta e na verdade dramática só tinha uma solução, e esta singularmente humorística.

Mil burros mansos valiam na emergência por dez mil heróis. A luta com todo o seu cortejo de combates sanguentos descambava, deploravelmente prosaica, a um plano obscuro.

Dispensava o heroísmo, desdenhava o gênio militar, excluía o arremesso das brigadas, e queria tropeiros e azêmolas. Esta maneira de ver implicava com o lirismo patriótico e doía, feito um epigrama malévolo da História, mas era a única. Era forçada a intrusão pouco lisonjeira de tais colaboradores em nossos destinos. O mais caluniado dos animais ia assentar, dominadoramente, as patas entaloadas em cima de uma crise, e esmagá-la...

Etimologicamente "reticência" significa "silêncio obstinado" e se compõe do prevérbio "re", indicador de reforço, do radical do verbo "tacere", calar-se, mais o sufixo formador de substantivos. Na sua significação ordinária e atual, o vocábulo "reticência", no singular, significa (1) supressão ou omissão voluntária de coisa que poderia ter sido dita, (2) a própria coisa omitida, (3) atitude de quem hesita em dizer expressamente o seu pensamento. "Reticências", no plural, significa os três pontos dispostos paralelamente à linha e ao lado de palavra, usados para marcar pausa, podendo indicar omissão de alguma coisa que não se quer revelar, emoção demasiada, insinuação, etc. ${ }^{20}$

Na gramática, são apontados os seguintes usos das reticências: para marcar (1) interrupção de ideia, (2) suspensão provocada por hesitação, surpresa, dúvida ou timidez, (3) certas inflexões de tristeza, cólera, sarcasmo, etc.,

16 ROSA. Ficção completa, v. 1, p. 225.

17 ROSA. Ficção completa, v. 1, p. 232.

18 ROSA. Ficção completa, v. 1, p. 199-200.

19 CUNHA. Os sertões, p. 665.

20 HOUAISS. Dicionário Honaiss da língua portuguesa, p. 2445. 
(4) para indicar que a ideia expressa não se completa com o fim do período e deve ser suplementada com a imaginação do leitor. Além disso, as reticências se empregam (5) para reproduzir, nos diálogos, o corte da frase de um personagem pela interferência de outro, e (6) antes de uma palavra ou de uma expressão que se quer realçar.

Lausberg afirma que a reticência (ou aposiopese) é a interrupção de um pensamento ou de uma cadeia de pensamentos, servindo como fórmula de transição para outro assunto; pode corresponder também à inexprimibilidade da situação e ser desse modo uma forma de ênfase do pensamento, além de esconder a dificuldade em que se encontra o orador. ${ }^{22}$ Reticência como figura retórica ultrapassa o uso do sinal gráfico reticências, mas, sem dúvida, este não pode ser deixado de lado, quando se trata de uma reflexão sobre o assunto.

O uso que Euclides faz das reticências em Os sertões, certamente, pode ser pensado levando-se em conta o que foi dito acima; porém, teceremos um comentário inconcluso, ou seja, reticente, do uso das reticências em Os sertões.

O que chama a atenção primeiramente, além do emprego generalizado das reticências em toda a obra, a ponto de elas não faltarem em nenhum dos capítulos e subcapítulos, é que as suas três grandes subdivisões ("A terra", "O homem" e "A luta") terminam em reticências, isto é, não se entregam a uma percepção única. Essa matéria feita de ruído e silêncio funciona como moldura que não limita o assunto, mas é convite à sua ultrapassagem. As reticências, dispostas estrategicamente nos finais de cada parte, me conduzem a pensá-las como elo entre partes de um tríptico, cuja leitura não se faz apenas em sentido sucessivo, mas numa leitura em camadas.

$O$ primeiro sinal de reticências que aparece no texto tem um sentido tópico, pois demarca o limite do incipit do livro, formado pelo primeiro e segundo parágrafos; além disso, representa o movimento descendente do olhar, que começa num sobrevoo panorâmico, seguido de um travelling, até se deter em plongée no "âmago da terra" e de novo se abrir para o horizonte. Esse efeito de prolongamento da paisagem, apondo logo em seguida à sua descrição os sinais de reticências, se caracterizará como um de seus usos mais recorrentes na obra em questão. Trata-se de um apelo de natureza visual muito bem representado pelos três pontos. Esse olhar reticente pode estar dirigido ao horizonte, aos meandros da paisagem e pode se elevar aos céus.

21 CUNHA; CINTRA. Nova gramática do português contemporâneo, p. 625-653.

22 LAUSBERG. Elementos de retórica literária, p. 197-257. 
As reticências também contêm um apelo de natureza auditiva. São inúmeros os exemplos que enfeixam o mesmo tipo de efeito. São as descrições dos estrépitos das batalhas, os tiros, seguidos de longos silêncios, gritos e preces. Exemplo curioso é este, em que o autor explicita o seu modo de operar autorreflexivamente a imagem sonora e visual: " $\mathrm{E}$ iam-se os dias, nesse intermitir de refregas furiosas e rápidas, e longas reticências de calma pontilhadas de balas..."

Para além dos efeitos visuais e auditivos, as reticências também apontam para um efeito sinestésico de sensações da ordem do assombro e da vertigem, do vazio e da impotência, que envolvem o observador inteiramente.

Os silêncios que permeiam a prosa euclidiana dizem também algo sobre a natureza ambígua do narrador. "Cerremos esta página perigosa...." , assim se encerra um dos segmentos da obra. Trabalhando nas fronteiras da ciência e da arte, Euclides procurou valer-se dos limites da primeira e das sugestões de liberdade da outra para mobilizar a sua escritura. Atos de degola, estripação e fuzilamento em massa de prisioneiros são representados iconicamente pelas reticências. O segmento intitulado "um grito de protesto" termina como uma elipse: "Mas que entre os deslumbramentos do futuro caia, implacável e revolta; sem altitude, porque a deprime o assunto; brutalmente violenta, porque é um grito de protesto; sombria, porque reflete uma nódoa esta página sem brilho..." ${ }^{25}$ Adiante, em outro segmento, o autor retoma essa imagem, dizendo: "Forremo-nos à tarefa de descrever os seus últimos momentos. Nem poderíamos. Esta página, imaginamo-la sempre profundamente emocionante e trágica; mas cerremo-la vacilante e sem brilhos" ${ }^{26}$. Trata-se da "eloquência silenciosa", paradoxo euclidiano para expressar o mesmo mutismo, em que sucumbiu Mário de Andrade alguns anos mais tarde.

Os dois últimos períodos do livro se estruturam como um quiasmo: "Ali estavam, no relevo de circunvoluções expressivas, as linhas essenciais do crime e da loucura..." ${ }^{28} /$ "É que ainda não existe um Maudsley para as loucuras e os crimes das nacionalidades...." Essa estrutura espelhada, de reflexo invertido, traz em seu bojo a ironia final do narrador. Destacada em capítulo à parte,

23 CUNHA. Os sertões, p. 587.

24 CUNHA. Os sertōes, p. 430

25 CUNHA. Os sertões, p. 738 .

26 CUNHA. Os sertões, p. 778-779.

27 CUNHA. Os sertões, p. 307.

28 CUNHA. Os sertôes, p. 780

29 CUNHA. Os sertões, p. 781. (Grifos nossos.) 
intitulado "Duas linhas", essa ironia guarda uma feição machadiana, no seu laconismo e na sua contundência. Como a ironia pressupõe uma participação ativa do receptor, no sentido de perceber, nas entrelinhas do dito, o não dito, as reticências funcionam como frestas, como os vazios da linguagem, no qual se projetam o olhar e a escuta do leitor. Por sua natureza lacunar, hesitante e suspensiva, elas também funcionam como signo da "fragilidade da palavra humana" ${ }^{30}$, que só produz significação mais profunda e plural, incorporando o silêncio e os ruídos como elementos constitutivos de sua natureza total.

\section{Os sertôes: a lacunar reading}

Abstract: Notwithstanding the acknowledged importance of Os sertoes [Rebellion in the Backlands], by Euclides da Cunha, for the development of Brazilian social thought, in this reading we intend to highlight the aesthetic and literary aspects of Cunha's work without, however, denying its relations with science and with the historical and social context portrayed in the book.

Keywords: Backlands, Science, Literature.

$$
\text { Referências }
$$

ABREU, Modesto de. Estilo e personalidade de Euclides da Cunha: estilística dOs sertões. Rio de Janeiro: Civilização Brasileira, 1963.

ANDRADE, Mário de. O turista aprendiz. 2 ed. São Paulo: Duas Cidades, 1983.

ASSIS, Machado de. Obra completa. Rio de Janeiro: Nova Aguilar, 1992. v. 3.

BOLLE, Willi. grandesertão.br ou: a invenção do Brasil. In: MADEIRA, A.; VELOSO, M. (Orgs.) Descobertas do Brasil. Brasília: UNB, 2001. p. 165-235.

CACASO. Lero-lero. São Paulo: Cosac \& Naify, 2002.

CUNHA, Celso; CINTRA, L. Nova gramática do português contemporâneo. 2 ed. Rio de Janeiro: Nova Fronteira, 1985.

CUNHA, Euclides da. Os sertões. Edição, prefácio, notas, e índice de Leopoldo M. Bernucci. São Paulo: Ateliê, 2002.

30 CUNHA. Os sertões, p. 779 
Belo Horizonte, p. 133-145

FORTES, Herbert P. Euclides: o estilizador de nossa história. 2 ed. Rio de Janeiro: GRD, 1959.

GALVÃO, Walnice; GALOTTI, O. Correspondência de Euclides da Cunha. São Paulo: EDUSP, 1997.

HOUAISS, Antônio. Dicionário Houaiss da língua portuguesa. Rio de Janeiro: Objetiva, 2001.

LAUSBERG, Heinrich. Elementos de retórica literária. Tradução, prefácio e aditamentos de R. M. Rosado Fernandes. 4 ed. Lisboa: Calouste Gulbenkian, 1993.

ROSA, J. Guimarães. Ficção completa. Rio de Janeiro: Nova Aguilar, 1994. v. 1. 
